\title{
Subclinical mastitis in goats is associated with upregulation of nitric oxide-derived oxidative stress that causes reduction of milk antioxidative properties and impairment of its quality
}

\author{
Nissim Silanikove,${ }^{* 1}$ Uzi Merin, $†$ Fira Shapiro, ${ }^{*}$ and Gabriel Leitnerł \\ *Biology of Lactation Laboratory, Institute of Animal Science, and \\ †Department of Food Quality and Safety, Postharvest and Food Sciences, A.R.O., the Volcani Center, PO Box 6, Bet Dagan 50250, Israel \\ $\ddagger$ National Mastitis Center, Kimron Veterinary Institute, PO Box 12, Bet Dagan 50250, Israel
}

\begin{abstract}
The aim of this study was to verify the existence of a nitric oxide (NO) cycle in goat milk and to study how changes in it affect milk composition during subclinical mastitis. Fifteen lactating dairy goats in which one udder-half was free from bacterial infection and the contra-lateral one was naturally infected with various species of coagulase-negative staphylococci were used. In comparison to uninfected glands, subclinical mastitis was associated with a decrease in milk yield, lactose concentration, and curd yield and an increase in nitrite and nitrate concentrations and with measurements reflecting increased formation of NO-derived free-radical nitrogen dioxide. The occurrence of NO cycling in goat milk was largely confirmed. The increase in the NOderived stress during subclinical infection was not associated with significant increase in oxidatively modified substances, 3-nitrotyrosine, and carbonyls on proteins, but with increased levels of peroxides on fat. However, the relatively modest nitrosative stress in subclinically infected glands was associated with significant reduction in total antioxidant capacity and vitamin $\mathrm{C}$ levels in milk. We concluded that subclinical mastitis in goats caused by coagulase-negative staphylococci imposes negative changes in milk yield, milk quality for cheese production, and negatively affects the nutritional value of milk as food. Thus, subclinical mastitis in goats should be considered as a serious economic burden both by farmers and by the dairy industry.
\end{abstract}

Key words: goat, milk, subclinical mastitis, oxidative stress, antioxidant capacity

\section{INTRODUCTION}

The quality of dairy products depends on that of the raw milk, which is, in turn, primarily affected by

Received August 4, 2013.

Accepted February 24, 2014.

${ }^{1}$ Corresponding author: nsilanik@agri.huji.ac.il animal health, milking intervals, milk storage, and time until processing (Roupas, 2001; Leitner et al., 2008b). Reduction in goat milk quality will have a negative influence on its industrial value, as most of the milk is processed into fermented products and cheese.

Quality and quantity of milk in dairy animals, including goats, was found to be mainly affected by subclinical IMI (Leitner et al., 2008a; Silanikove et al., 2010), mainly due to various CNS (Djabri et al., 2002; Leitner et al., 2004b; Taponen et al., 2006). In dairy cows, subclinical mastitis has only moderate projection on bulk milk because of the low increase in SCC in the infected glands (Pitkälä et al., 2004; Leitner et al., $2008 \mathrm{~b}$ ) and the dilution effect of the 4 quarters. However, the influence of the infection reflected by SCC on the animal level is relatively high in sheep and goats compared with cows because of the strong immune response to the infection and the existence of only 2 mammary glands (Leitner et al., 2011).

Milk from mastitic udders exhibits increased proteolytic activity (Le Roux et al., 1995; Leitner et al., 2011). Plasmin (PL) is the most important protease in milk from both healthy udders and udders with elevated SCC, but the nonplasmin proteases become more important with increased severity of udder inflammation (O'Farrell et al., 2002; Leitner et al., 2004b, 2011). Proteolysis of casein leads to a decrease in the relative proportion of caseins (especially $\beta-\mathrm{CN}$ and $\alpha_{\mathrm{s} 1^{-}}$ $\mathrm{CN})$ with simultaneous pronounced increase of $\gamma$-CN and proteose peptones (Silanikove et al., 2006). During the last decade, our laboratories extensively studied the physiological basis for the reductions in milk yield and its quality under exposure to IMI and stress (Silanikove et al., 2006, 2012; Leitner et al., 2011). Collectively, these studies have shown that enzymatic hydrolysis of casein by PL liberates peptides that serve as local regulators of mammary gland functions, which is reflected by simultaneous reduction in milk yield in the infected glands and the inability of the milk of those glands to coagulate (Leitner et al., 2011). Recently, we have shown that tissue type of plasminogen activator 
(PA) in cow milk is closely associated with the casein micelles, and that it is responsible for casein hydrolysis (Politis, 1996; Silanikove et al., 2013).

Subclinical and clinical mastitis in cows was found to be associated with an increase in the concentration of nitric oxide (NO)-derived metabolites, nitrite and nitrate (Silanikove et al., 2005, 2007). It was concluded that the NO cycle and its components in milk are important parts of the gland innate immune system in defending against invading pathogens, albeit it may be associated with nitrosative stress and impairment of milk oxidative stability (Silanikove et al., 2009, 2012), which may increase the sensitivity of milk proteins to proteolysis (Leitner et al., 2006; Silanikove et al., 2006).

The cycling of $\mathrm{NO} \bullet$ in milk was demonstrated so far only in cows. The aims of the present study were to verify the existence of $\mathrm{NO}$ cycling in goat milk and to examine how subclinical mastitis caused by various species of CNS affects the rate of NO cycling and milk composition. In particular, we examined how subclinical mastitis affects the total antioxidant capacity and milk quality for curdling.

\section{MATERIALS AND METHODS}

\section{Animals}

Fifteen Israeli goats, mainly Saanen or Alpine $\times$ Anglo Nubian were selected from a commercial farm that was intensively monitored for research purposes. For each animal, 1 udder half was naturally infected with an identified single species of CNS and the contralateral gland was free of bacteria. Prior to animal selection, milk samples from each udder half were subjected to 3 consecutive weekly examinations to test for bacterial infection and SCC. The CNS were of various species but due to their low number, each analysis was performed across species. The selected goats were in mid lactation and their daily milk yield exceeded $2.5 \mathrm{~L}$. Goats were machine milked twice daily at 0500 and $1500 \mathrm{~h}$. Postmilking teat dipping was practiced, and the animals were kept in an open shelter providing $4 \mathrm{~m}^{2}$ of shaded slatted floor and $4 \mathrm{~m}^{2}$ of concrete-surfaced yard/goat. Goats were fed a high-quality TMR and hay (Lucerne), which provided $60 \%$ concentrate, $40 \%$ NDF, and $17 \%$ protein. Feed was offered in mangers and water in the shades was available at all time.

\section{Milk Sampling and Analysis}

On the test day, milk sampling and yield measurements were carried out during the morning milking. Yield was determined by weighing the milk of each udder half of each goat after hand milking and multiplying by
1.7. For the bacteriological tests, the teats were cleaned and disinfected and the milk was sampled and analyzed by accepted standards (Leitner et al. 2004a; Oliver et al., 2004). Three additional sets of samples were taken from each udder half and distributed for analysis as follows. One set $(40 \mathrm{~mL})$ was preserved by means of Broad Spectrum Microtabs II (D \& F Control Systems Inc., Norwood, MA) and sent to a central laboratory (Cattle Breeders Association Laboratory, Caesarea, Israel) for analysis of the milk gross composition: protein, fat, and lactose contents (MilkoScan 6000; Foss Electric A/S, Hillerød, Denmark) and SCC (Fossomatic 360; Foss Electric A/S), all calibrated with goat milk. The second set of samples $(20 \mathrm{~mL})$ was used to determine rennet clotting time and curd firmness after 60 min with the Optigraph instrument (Ysebaert, Frépillon, France). A third set $(300 \mathrm{~mL})$ of milk was defatted at $4^{\circ} \mathrm{C}$ and caseins, whey proteins, proteose peptones (p-p), PA, plasminogen (PLG), and PL activities were analyzed in the skim milk (Shamay et al., 2000, 2003; Silanikove et al., 2000). The repeated addition procedure was used to measure the concentrations of free (ionized) calcium $\left(\mathrm{Ca}^{2+}\right)$ and the uncorrected procedure was used to determine calcium activity in these samples within $5 \mathrm{~h}$ of sampling by means of a specific calcium electrode (Silanikove et al., 2003). The third set was also used to analyze metabolites, the procedure of which was described in detail earlier (Silanikove et al., 2005, 2009). Nitrite was analyzed by a fluorometric method and nitrate was determined colorimetrically by the Griess reagent (Silanikove et al., 2005); uric acid was analyzed as the product of purines metabolism in milk (Silanikove et al., 2007). The measure of the activities of xanthine oxidase, lactoperoxidase, and catalase (CAT) was carried out as described in Silanikove et al. (2005, 2009).

The discoloration of $\beta$-carotene added to milk samples was used to determine the oxidation reaction that results from the formation of free radicals in milk. The reaction took place in a cuvette that contained 14 $\mu M \beta$-carotene and $0.05 \%$ Tween 20 in $1.7 \mathrm{~mL}$ of 0.1 $M$ sodium acetate buffer. The reaction was started by adding a $0.3-\mathrm{mL}$ sample. The decrease in absorbance at $460 \mathrm{~nm}$ as measured during the first $30 \mathrm{~s}$ was used to calculate the rate of $\beta$-carotene bleaching.

The conversion of 5-thio-2-nitrobenzoic acid (TNB) into 5,5'-dithiobis-2-nitrobenzoate (DTNB) was used as a measure of the formation of potent radicals, such as nitric dioxide. The TNB was prepared by reduction of $1 \mathrm{~m} M$ DTNB in $100 \mathrm{~mL}$ of $50 \mathrm{~m} M$ sodium phosphate buffer ( $\mathrm{pH} 7.4$ ) with $4 \mu \mathrm{L}$ of 2 -mercaptoethanol. The test sample was placed in a cuvette that contained 40 $\mu M$ TNB in $1.8 \mathrm{~mL}$ of $50 \mathrm{~m} M$ sodium phosphate buffer (pH 7.4). The reaction was started by adding a $0.2-\mathrm{mL}$ sample. The decrease in absorbance at $412 \mathrm{~nm}$ during 
the first $10 \mathrm{~s}$ was used to calculate the rate of oxidation of TNB to DTNB (Cary Eclipse spectrophotometer; Varian Inc., Palo Alto, CA). All the reagents used for the assays performed in this work were purchased from Sigma-Aldrich (Rehovot, Israel).

Nitrotyrosine (Ntyr) and carbonyl concentrations were determined in whey proteins. As the last stage in both determinations was colorimetric, the concentration was determined after clarification of the milk to a crystal-clear solution following skimming and casein precipitation by ultracentrifugation at $100,000 \times g$ for $2 \mathrm{~h}$ at $10^{\circ} \mathrm{C}$. Nitrotyrosine was determined by ELISA (Tecan GENios Plus; Tecan Group Ltd., Männedorf, Switzerland) with monoclonal antibodies against Ntyr and carbonyls were determined by color reaction. The Ntyr and carbonyl concentrations were determined in whey proteins; Ntyr was determined by ELISA, using mononuclear antibody against Ntyr and carbonyl by colorimetric reaction. The lower detection limit of the ELISA reader was approximately $20 \mathrm{nmol}$ of Ntyr/L. The coefficients of variation ranged from approximately $5 \%$ for a concentration of $250 \mathrm{ng} /$ well to approximately $7 \%$ for a concentration of $60 \mathrm{ng} /$ well, and all the results recorded were within this range. Both measurements were carried out in the ELISA plate reader and both were related to the protein content in the whey, which was determined colorimetrically. Lipid peroxides ( $\mathbf{L p x})$ were determined in the separated milk fat samples and were related to grams of fat. All the above methods were performed as described in detail by Silanikove et al. (2005).

The total antioxidant capacity (TAC) of skim milk was analyzed by the method of measuring ferric-reducing ability of plasma (FRAP; Chen et al., 2003).

Ascorbic acid (vitamin C) concentration was determined colorimetrically in clear whey, (i.e., in ultracentrifuge samples; Silanikove and Shapiro, 2007) according to the procedure of Das et al. (1998). Special care was taken to prevent the samples from exposure to light.

\section{Statistical Analysis}

The dependent variables were the data of the measures described in the Milk Sampling and Analysis section. Analysis of SCC was carried out on the logarithmically transformed numbers. Data were analyzed with JMP statistical software (SAS Institute, 2002) under a randomized block design in which goats served as blocks. Within each block, there were 2 levels of bacteriological status, as follows:

$$
\mathrm{Y}_{\mathrm{ijk}}=\mu+\mathrm{G}_{\mathrm{i}}+\mathrm{B}_{\mathrm{j}}+\mathrm{e}_{\mathrm{ijk}},
$$

where $Y_{\mathrm{ijk}}=$ dependent variable; $\mu=$ overall mean; $G_{\mathrm{i}}$ $=$ goat $\mathrm{i}$, where $\mathrm{i}=1$ to $15 ; \mathrm{B}_{\mathrm{j}}=$ bacteriological status, where $\mathrm{j}=1$ (infected) or 2 (uninfected); and $\mathrm{e}_{\mathrm{ijk}}=$ error term (experimental variation between udder halves within a goat).

\section{RESULTS}

The effects of subclinical mastitis on milk yield, SCC, gross milk composition, p-p, and calcium levels in infected glands compared with the contralateral uninfected ones are summarized in Table 1. Milk yield of the infected glands was significantly lower $(P<0.001)$ than that of the uninfected ones and, in parallel, the index for infection response (SCC) was significantly higher $(P$ $<0.001)$ in the infected glands than in the uninfected ones. Lactose concentration in the infected glands was significantly lower $(P=0.004)$ than that in the uninfected glands. The concentration of fat, total protein, and casein did not differ between the uninfected and infected glands, whereas whey protein concentrations were higher $(+9.7 \% ; P>0.05)$ than in the uninfected ones. Curd firmness was significantly lower $(P<0.01)$ and rennet-clotting time was significantly longer $(P<$ $0.05)$ in the infected glands than in the uninfected ones (data not presented). The concentration of p-p was 2.3 times higher $(P<0.005)$ in the infected glands than in the uninfected ones. Free (ionized) calcium did not differ; whereas, calcium activity was significantly lower $(P<0.002)$ in the infected glands versus the uninfected glands (Table 1).

Plasminogen activator and PL activities were significantly higher in the infected glands than in the uninfected ones (Table 2). Plasminogen activity was very low to undetectable; therefore, these data are not presented. All the metabolite concentrations and enzyme activities were significantly higher in the infected glands than in the uninfected ones $(P<0.01$ or higher $)$ : nitrite: 2.3 times higher, nitrate: 8.7 times higher, uric acid: 2.2 times higher, S-nitrosamines: 2 times higher, xanthine oxidase: 2.3 times higher, lactoperoxidase: 5.3 times higher, and CAT: 3.6 times higher (Table 2).

The discoloration of $\beta$-carotene added to samples indicated that raw goat milk was under continuous assault by free radicals, resulting in the conversion of TNB to DTNB and that the rate of such exposure was significantly higher in the infected glands $(P<0.01)$ than in the uninfected ones (Table 2). The TAC level as measured by FRAP was $26.2 \%$ higher $(P<0.01)$ in the uninfected glands than in the infected glands. Ascorbic acid concentration in the uninfected gland was $36.4 \%$ higher $(P<0.01)$ than in the infected glands (Table 2 ).

The concentration of oxidatively modified products on proteins, Ntyr, and carbonyls tended to be higher $(P<0.10)$ in the infected glands than in the uninfected ones, whereas the concentration of Lpx on lipids was 
Table 1. Effect of subclinical mastitis on milk yield, SCC, gross milk composition, proteose peptones (p$\mathrm{p})$, and free (ionized) calcium $\left(\mathrm{Ca}^{2+}\right)$ and calcium activity $\left(\mathrm{a}_{\mathrm{Ca}}{ }^{2+}\right)$ in infected glands compared with the contralateral uninfected glands in goats $($ mean $\pm \mathrm{SE} ; \mathrm{n}=15)$

\begin{tabular}{lccc}
\hline Item & Uninfected & Infected & $P$-value \\
\hline Milk yield $(\mathrm{L} / \mathrm{d})$ & $1.63 \pm 0.08$ & $1.34 \pm 0.07$ & $<0.001$ \\
Log SCC $(/ \mathrm{mL})$ & $5.55 \pm 0.09$ & $6.20 \pm 0.02$ & $<0.001$ \\
Fat $(\mathrm{g} / \mathrm{L})$ & $39.0 \pm 1.0$ & $38.8 \pm 1.2$ & $\mathrm{NS}$ \\
Lactose $(\mathrm{g} / \mathrm{L})$ & $47.1 \pm 2.0$ & $42.1 \pm 2.2$ & 0.004 \\
Protein $(\mathrm{g} / \mathrm{L})$ & $34.6 \pm 0.5$ & $35.1 \pm 0.6$ & $\mathrm{NS}$ \\
Casein $(\mathrm{g} / \mathrm{L})$ & $28.3 \pm 0.7$ & $28.1 \pm 0.6$ & $\mathrm{NS}$ \\
Whey protein $(\mathrm{g} / \mathrm{L})$ & $6.2 \pm 0.3$ & $6.8 \pm 0.4$ & $\mathrm{NS}$ \\
$\mathrm{p}-\mathrm{p}(\mathrm{mg} / \mathrm{mL})$ & $0.38 \pm 0.09$ & $0.86 \pm 0.10$ & 0.01 \\
$\mathrm{a}^{2+}(\mathrm{m} M)$ & $2.15 \pm 0.15$ & $1.20 \pm 0.21$ & 0.01 \\
{$\left[\mathrm{Ca}^{2+}\right](\mathrm{m} M)$} & $3.5 \pm 0.5$ & $4.1 \pm 0.6$ & $\mathrm{NS}$ \\
\hline
\end{tabular}

higher $(P<0.05)$ in the infected glands compared with the uninfected ones (Table 2).

\section{DISCUSSION}

The physiological and technological significance of the data reported in Table 1 was considered in several reports (Silanikove et al., 2006, 2012; Leitner et al., 2011). Therefore, we relate here briefly to the main conclusions: The PL system plays a central role in regulating milk secretion and its activity is increased during subclinical and, to a higher extent, during clinical mastitis. Peptides derived by the activity of PL on casein, measured here as p-p, are involved in regulation of milk secretion and impeding clotting of the casein micelles and overall curdling efficiency (Merin et al., 2008; Fleminger et al., 2011, 2013). Lactose concentration in milk closely reflected both reduction in milk yield and deterioration of milk ability to curdle (Leitner et al., 2011). A recent report on bovine milk provided evidence and suggested that tissue-type PA and PLG are secreted and embedded within the casein micelles and rule its degradation (Silanikove et al., 2013). The unusually high PA:PLG ratio in goat milk can convert rapidly and effectively PLG into PL and explain why it is difficult to record PLG activity in goat milk (Baldi et al., 2002; Leitner et al., 2004b). The physiological significance of lacking measurable PLG in goat milk was discussed in Silanikove et al. (2010). Our data are also consistent with previous conclusions that reduction in calcium activity in milk is involved in impeding the ability of casein to coagulate (Leitner et al. 2004a,b) and is consistent with our recent reports showing that casein-derived p-p are rich in phosphorus and can bind free calcium and impede curdling (Fleminger et al., 2013).

Table 2. Effect of subclinical mastitis on plasmin (PL), plasmin activator (PA), concentration of metabolites, activity of enzymes composing the NO cycle, oxidative stress from free radicals [carotene destruction and formation of 5,5'-dithiobis-2-nitrobenzoate (DTNB)], antioxidative properties [ascorbic acid concentration and ferric-reducing ability of plasma (FRAP)] and formation of oxidatively modified substances [nitrotyrosine (Ntyr), lipid peroxides (Lpx), and carbonyls] in milk of infected glands compared with the contralateral glands of uninfected glands in goats (mean $\pm \mathrm{SE} ; \mathrm{n}=15$ )

\begin{tabular}{lccc}
\hline Item $^{1}$ & Uninfected & Infected & $P$-value \\
\hline PL $(\mathrm{U} / \mathrm{mL})$ & $18.3 \pm 3.0$ & $38.1 \pm 0.36$ & 0.05 \\
$\mathrm{PA}(\mathrm{U} / \mathrm{mL})$ & $3,390 \pm 125$ & $4,375 \pm 131$ & 0.01 \\
Nitrite $(\mu M)$ & $0.38 \pm 0.09$ & $0.86 \pm 0.10$ & $<0.01$ \\
Nitrate $(\mu M)$ & $2.15 \pm 0.05$ & $12.03 \pm 2.1$ & 0.01 \\
Uric acid $(\mu M)$ & $35.2 \pm 5.1$ & $94.1 \pm 6.2$ & 0.01 \\
S-Nitrosamines $(\mu M)$ & $0.17 \pm 0.02$ & $2.40 \pm 0.02$ & 0.01 \\
XO $(\mathrm{U} / \mathrm{mL})$ & $17.0 \pm 1.7$ & $30.1 \pm 4.1$ & 0.01 \\
LPO $(\mathrm{U} / \mathrm{mL})$ & $3.3 \pm 0.3$ & $18.1 \pm 1.6$ & $<0.01$ \\
Catalase $(\mathrm{U} / \mathrm{mL})$ & $2.6 \pm 0.1$ & $9.3 \pm 0.3$ & $<0.01$ \\
Carotene destruction $(\mathrm{nmol} / \mathrm{s})$ & $669 \pm 121$ & $2,006 \pm 215$ & $<0.001$ \\
DTNB formation $(\mathrm{nmol} / \mathrm{s})$ & $450 \pm 49$ & $1,816 \pm 91$ & 0.01 \\
FRAP $(\mu M)$ & $427 \pm 35$ & $305 \pm 36$ & 0.05 \\
Ascorbic acid $(\mu M)$ & $143 \pm 11$ & $91 \pm 7$ & 0.01 \\
Ntyr $(\mathrm{nmol} / \mathrm{g})$ & $110 \pm 47$ & $170 \pm 41$ & $\mathrm{NS}$ \\
Lpx $(\mathrm{mEq} / \mathrm{g})$ & $1.3 \pm 0.3$ & $2.8 \pm 0.6$ & $<0.05$ \\
Carbonyls $(\mathrm{nmol} / \mathrm{g})$ & $280 \pm 125$ & $357 \pm 131$ & NS
\end{tabular}

${ }^{1} \mathrm{U}=$ activity unit ( $1 \mathrm{U}$ is the amount of PL that produces a change in absorbance of 0.1 at $405 \mathrm{~nm}$ in $60 \mathrm{~min}$ ); $\mathrm{XO}=$ xanthine oxidase; $\mathrm{LPO}=$ lactoperoxidase. 
The data presented in Table 2 were the basis for deriving the concept that the NO cycle is an important component of the mammary gland immune system ( $\mathrm{Si}-$ lanikove et al., 2005, 2012). This concept was presented in a schematic model that described the simultaneous activation of the PA-PLG-PL system and the NOderived cycle following challenge of the cow mammary gland with LPS (Silanikove et al., 2012). The present scheme (Figure 1) adds additional information regarding the influence of CNS infection in goats. Accordingly, $\mathrm{NO} \bullet$ constantly cycles in milk through its autoxidation to nitrite, conversion of nitrite to the potent free radical $\mathrm{NO}_{2} \bullet$ (nitric dioxide), interaction of $\mathrm{NO}_{2} \bullet$ with thyl radicals formed by $\mathrm{NO} \bullet$ to form S-nitrosothiols, and disintegration of $\mathrm{NO} \bullet$ from S-nitrosothiols, completing the cycle (Figure 1). Two major reactions in this cycle are $\mathrm{H}_{2} \mathrm{O}_{2}$ dependent: the first is conversion of nitrite to $\mathrm{NO}_{2} \bullet$ and the second is CAT-dependent conversion of nitrite to nitrate, which serves as the main mechanism to restrain this cycle (Silanikove et al., 2009). Xanthine oxidase, by oxidizing purines (xanthine/hypoxanthine) into uric acid was identified as the major source of $\mathrm{H}_{2} \mathrm{O}_{2}$ formation in milk. Uric acid concentrations were increased under subclinical mastitis in bovines (Silanikove et al., 2007), as also found here in goats and to a larger extent during acute-clinical mastitis in bovines (Silanikove et al., 2012). Thus, the data presented here strongly suggest that NO cycling occurs also in goat milk.

The TAC level of skim milk in the uninfected glands in the present study as FRAP $(427 \mu M)$ is considerably higher than the equivalent measurements in cows (219 $\mu M$; Chen et al., 2003). The FRAP method assesses the ability of a sample to reduce ferric ions and, thus, can be used as a criterion of the antioxidation capacity because small molecules such as ascorbic acid, uric acid, and $\alpha$-tocopherol were found to have ferric-reducing ability. It was concluded that the FRAP method is particularly effective for measuring TAC of low molecular weight in milk (Chen et al., 2003). Consistently, the ascorbic acid concentration found in the present study in goat milk $(143 \mu M)$ was higher than that found in cow milk $(119 \mu M)$ supplemented with vitamin C (Weiss, 2001). Catalase plays a critical role in milk by restraining the NO cycle by converting nitrite into less active nitrate (Silanikove et al., 2009). Catalase activity in uninfected glands of goats reported here $(3.8 \mathrm{U} / \mathrm{mL})$ was higher than in uninfected glands of cows $(2.1 \mathrm{U} / \mathrm{mL})$. Furthermore, in 3 separate studies, the TAC of goats milk was found to be superior to that in the compared species: cows and donkeys (Simos et al., 2011); humans, cows, buffalo, and ewes (Öner et al., 2011); and cows (Bysokogorskiǐ and Veselov, 2010); the latter study also sustained that goat milk contains higher levels of ascorbic acid and - $\mathrm{SH}$ groups on pro- teins. It was shown that 40-d consumption of $0.6 \mathrm{~L} / \mathrm{d}$ of Prisca goat milk (a Greek breed with a high level of TAC) significantly increased TAC in the blood of healthy volunteers (Simos et al., 2011) and that goat milk consumption improved antioxidant defense during Fe-deficiency anemia recovery (Diaz-Castro et al., 2011). The evidence suggests that the TAC capacity of goat milk is superior to that of cow milk and likely other mammals, which relates to higher concentrations of components that contribute to TAC, such as vitamin $\mathrm{C}$, or prevent oxidative stress, such as CAT.

As in cows (Silanikove et al., 2009, 2012), it was found in the present study that even milk from uninfected glands contains oxidatively modified substances: Ntyr and carbonyls on proteins and Lpx on fat. It was suggested that the source of these substances in milk is cellular oxidative stress associated with milk synthesis, particularly with the high usage of glucose by the mammary gland epithelial cells (Silanikove et al., 2009). The concentration of these oxidatively modified substances in goats is considerably lower than in cows (present work versus Silanikove et al., 2009), which suggests that milk synthesis in goats occurs under lower oxidative stress in comparison with cows.

In agreement with the response study in cows (Titov et al., 2010), subclinical mastitis was associated with increased nitrate and nitrite concentrations, which suggests that subclinical mastitis is associated with upregulation of the NO cycle due to increased release of NO• into milk, as previously indicated. However, whereas in cow milk the nitrite level accumulated from an undetectable level to 2 to $3 \mu M$ (Titov et al., 2010), in goats it remained on the sub-micromolar range. In cows, the increase in nitrite concentration was associated with nitrosative stress (i.e., accumulation of oxidatively modified substances). On the other hand, in goats, milk nitrosative stress on proteins was largely prevented and only fat, which is inherently more sensitive to oxidation, exhibited nitrosative stress in the form of accumulation of Lpx. The prevention and attenuation of nitrosative stress may be partially explained by reductive consumption of ascorbic acid and the higher levels of CAT in goats compared with cow milk. In fact, the approximately $25 \%$ decrease in FRAP in the infected glands compared with uninfected ones is much lower than the increase in NO•-related stress that can be evaluated from the $2.5 \times$ increase in nitrite concentration in milk. This discrepancy may be explained by the increase in TAC from the increased content of uric acid, a known antioxidant; from accumulation of p-p, of which many possess antioxidative properties (Lindmark-Månsson and Åkesson, 2000); and the large increase in CAT activity.

In conclusion, the NO cycle in goats and cows share considerable similarities, albeit the ability to restrain 


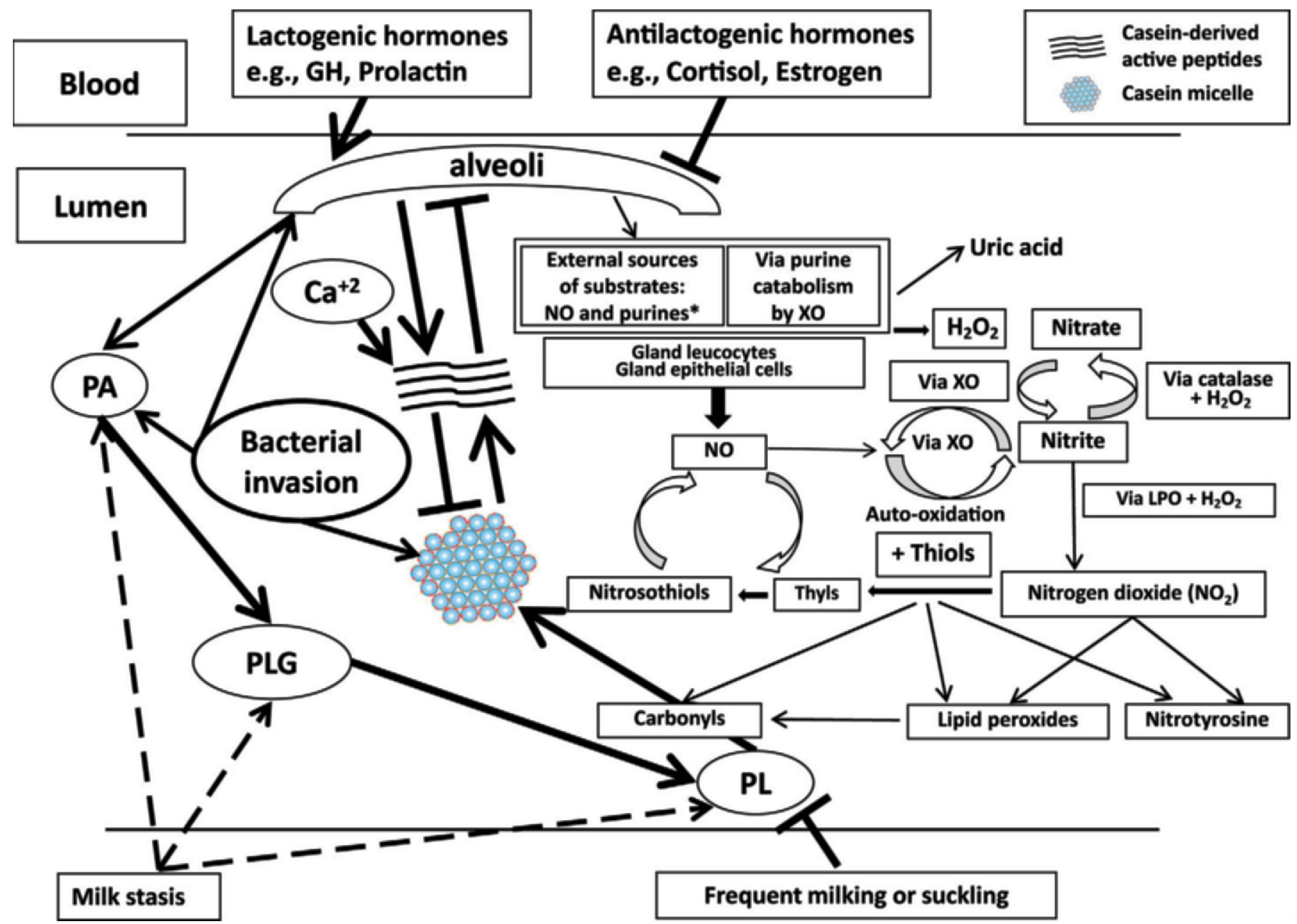

Figure 1. Schematic model that describes the simultaneous activation of the plasminogen activator-plasminogen-plasmin (PA-PLG-PL) system and the nitric oxide (NO)-derived cycle in subclinically infected mammary glands. The increased activity of PL causes release of peptides from the casein micelles, which, in turn, downregulates milk secretion and casein micelles clotting (Leitner et al., 2011; Silanikove et al., 2012). The release of peptides that are rich in phosphates impairs the coagulation of milk by reducing $\mathrm{Ca}^{+2}$ availability (Leitner et al., 2004a,b; Fleminger et al., 2013). In parallel, subclinical mastitis upregulates the NO-cycle rate in milk, by at least 3 pathways: (1) direct activation of the plasmin system and the immunostimulating effect of the released peptides, (2) casein proteolysis by enzymes released by the infected bacteria and potential immunostimulating effect of the released peptides, and (3) direct (e.g., by endotoxins) and indirect (activation of secretion of various cytokine from milk leukocytes and mammary epithelial cells) activation of the mammary gland innate immune system. The increased release of NO into milk is associated with upregulation of formation of bactericide radical (nitric dioxide), which may result in an increased formation of nitrotyrosine, carbonyls and lipid peroxide (Silanikove et al., 2005, 2009). Hydrogen peroxide plays important role in the NO cycle by its use as substrate for lactoperoxidase in forming nitric dioxide and as substrate for catalase in conversion of nitrite to nitrate. The later reaction is the main mechanism, which restrains the NO cycle in milk. The source of hydrogen peroxide in milk is oxidation of xanthine and hypoxanthine by xanthine oxidoreductase, which results in accumulation of uric acid as the end product of the xanthenes oxidation. The increased content of oxidized components in milk most likely increase their susceptibility to proteolysis (Leitner et al., 2006; Silanikove et al., 2006). GH $=$ growth hormone; $\mathrm{LPO}=$ lactoperoxidase; $\mathrm{NO}=$ nitric oxide; $\mathrm{PA}=$ plasminogen activator; $\mathrm{PL}=$ plasmin; $\mathrm{PLG}=$ plasminogen; XO = xanthine oxidoreductase. Color version available in the online PDF.

the effects of $\mathrm{NO}_{2} \bullet$ and prevent oxidative damage to milk OM is more efficient in goats than in cows.

\section{CONCLUSIONS}

In the present study, it was confirmed that subclinical mastitis caused by CNS is associated with significant losses in milk yield and quality for cheese production. Milk of subclinically infected glands is subjected to considerable oxidative stress derived from $\mathrm{NO} \bullet$ release into milk, which only moderately imposes nitrosative stress on milk proteins. However, it is associated with significant loss of milk antioxidant capacity and vitamin C levels, which are particularly high in goats. We conclude that subclinical mastitis induces unfavorable changes in milk quantity and composition, which affects considerably both the farmers and the dairy sector that depend on goat milk, and deteriorates its nutritional value to consumers. 


\section{REFERENCES}

Baldi, A., S. Modina, F. Cheli, F. Gandolfi, L. Pinotti, L. Baraldi Scesi, F. Fantuz, and V. Dell'Orto. 2002. Bovine somatotropin administration to dairy goats in late lactation: Effects on mammary gland function, composition and morphology. J. Dairy Sci. 85:1093-1102.

Bysokogorski1̄, V. E., and P. V. Veselov. 2010. [Estimation of antioxidizing properties of goat and cow milk]. Vopr. Pitan. 79:56-58. [Article in Russian.]

Chen, J., H. Lindmark-Månsson, L. Gorton, and B. Åkesson. 2003. Antioxidant capacity of bovine milk as assayed by spectrophotometric and amperometric methods. Int. Dairy J. 13:927-935.

Das, J. V., V. K. Gupta, and M. K. Rai. 1998. A sensitive colorimetric method determination of ascorbic acid in food, pharmaceuticals and biological samples. Chemia Analityczna 43:85-92.

Diaz-Castro, J., M. Ramirez Lopez-Frias, M. M. Alferez, T. Nestares, I. Lopez-Aliaga, and M. S. Campos. 2011. Goat milk consumption improves antioxidant defense during Fe-deficiency anaemia recovery. Ann. Nutr. Metab. 58(Suppl. 3):287.

Djabri, B., N. Bareille, F. Beaudeau, and H. Seegers. 2002. Quarter milk somatic cell count in infected dairy cows: A meta-analysis. Vet. Res. 33:335-357.

Fleminger, G., H. Ragones, U. Merin, N. Silanikove, and G. Leitner. 2011. Characterization of casein-derived peptides generated by bacterial enzymes during sub-clinical intramammary infection. Int. Dairy J. 21:914-920.

Fleminger, G., H. Ragones, U. Merin, N. Silanikove, and G. Leitner. 2013. Low molecular mass peptides generated by hydrolysis of casein impair rennet coagulation of milk. Int. Dairy J. 30:74-78.

Le Roux, Y., J. M. Girardet, G. Humbert, F. Laurent, and G. Linden. 1995. Proteolysis in samples of quarter milk with varying somatic cell counts. 2. Component PP3 and $\beta$-casein-1P (f29-105 and f29107) of the proteose-peptone fraction. J. Dairy Sci. 78:1298-1305.

Leitner, G., O. Krifucks, U. Merin, Y. Lavi, and N. Silanikove. 2006. Interactions between bacteria type, proteolysis of casein and physico-chemical properties of bovine milk. Int. Dairy J. 16:648-654.

Leitner, G., U. Merin, and N. Silanikove. 2004a. Changes in milk composition as affected by subclinical mastitis in goats. J. Dairy Sci. 87:1719-1726.

Leitner, G., U. Merin, and N. Silanikove. 2008a. Estimate of milk and curd yield loss of sheep and goats with intrammamary infection and its relation to somatic cell count. Small Rumin. Res. $74: 221-225$.

Leitner, G., U. Merin, and N. Silanikove. 2011. Effects of glandular bacterial infection and stage of lactation on milk clotting parameters: Comparison among cows, goats and sheep. Int. Dairy J. $21: 279-285$.

Leitner, G., U. Merin, N. Silanikove, E. Ezra, M. Chaffer, N. Gollop, M. Winkler, A. Glickman, and A. Saran. 2004b. Effect of subclinical intramammary infection on somatic cell counts, NAGase activity and gross composition of goats' milk. J. Dairy Res. 71:311-315.

Leitner, G., N. Silanikove, S. Jacobi, L. Weisblit, S. Bernstein, and U. Merin. 2008b. The influence of storage on the farm and in dairy silos on milk quality for cheese production. Int. Dairy J. 18:109-113.

Lindmark-Månsson, H., and B. Åkesson. 2000. Antioxidative factors in milk. Br. J. Nutr. 84(Suppl. 1):S103-S110.

Merin, U., G. Fleminger, J. Komanovsky, N. Silanikove, S. Bernstein, and G. Leitner. 2008. Subclinical udder infection with Streptococcus dysgalactiae impairs milk coagulation, properties: The emerging role of proteose peptones. Dairy Sci. Technol. 88:407-419.

O'Farrell, I. P., J. J. Sheehan, M. G. Wilkinson, D. Harrington, and A. L. Kelly. 2002. Influence of addition of plasmin or mastitic milk to cheese milk on quality of smear-ripened cheese. Lait 82:305-316.

Oliver, S. P. R. N. Gonzalez, J. S. Hogan, B. M. Jayarao, and W. E. Owens. 2004. Micro-biological Procedures for the Diagnosis of Bovine Udder Infection and Determination of Milk Quality. 4th ed. National Mastitis Council Inc., Verona, WI.

Öner, Z., H. Sanlıdere-Aloğlu, and T. Dedebaş. 2011. Determination of antioxidant capacity in milk from various animals and humans. Milchwissenschaft 66:133-135.
Pitkälä, A., M. Haveri, S. Pyörälä, V. Myllys, and T. Honkanen-Buzalski. 2004. Bovine mastitis in Finland 2001-Prevalence, distribution of bacteria, and antimicrobial resistance. J. Dairy Sci. $87: 2433-2441$.

Politis, I. 1996. Plasminogen activator system: Implication for mammary cell growth and involution. J. Dairy Sci. 79:1097-1107.

Roupas, P. 2001. On-farm practices and post farmgate processing parameters affecting composition of milk for cheesemaking. Aust. J Dairy Technol. 56:219-232.

SAS Institute. 2002. JMP Statistics and Graphics Guide, Version 5. SAS Institute Inc., Cary, NC.

Shamay, A., G. Leitner, F. Shapiro, and N. Silanikove. 2003. Casein hydrolyzates disrupt tight junction integrity and induced involution in cows. J. Dairy Sci. 86:1250-1258.

Shamay, A., S. J. Mabjeesh, F. Shapiro, and N. Silanikove. 2000. Adrenocorticotrophic hormone and dexamethasone failed to affect milk yield in dairy goats: Comparative aspects. Small Rumin. Res. $38: 255-259$.

Silanikove, N., G. Leitner, U. Merin, and G. C. Prosser. 2010. Recent advances in exploiting goat's milk: Quality, safety and production aspects. Small Rumin. Res. 89:110-124.

Silanikove, N., U. Merin, and G. Leitner. 2006. Physiological role of indigenous milk enzymes: An overview of an evolving picture. Int. Dairy J. 16:533-545.

Silanikove, N., A. Rauch-Cohen, F. Shapiro, A. Arieli, U. Merin, and G. Leitner. 2012. Lipopolysaccharide challenge of the mammary gland in cows induces nitrosative stress that impaired milk oxidative stability. Animal 6:1451-1459.

Silanikove, N., A. Shamay, D. Shinder, and A. Moran. 2000. Stress down regulates milk yield in cows by plasmin induced $\beta$-casein product that blocks $\mathrm{K}^{+}$channels on the apical membranes. Life Sci. $67: 2201-2212$

Silanikove, N., and F. Shapiro. 2007. Distribution of xanthine oxidase and xanthine dehydrogenase activity in bovine milk: Physiological and technological implications. Int. Dairy J. 17:1188-1194.

Silanikove, N., F. Shapiro, and G. Leitner. 2007. Posttranslational ruling of xanthine oxidase activity in bovine milk by its substrates. Biochem. Biophys. Res. Commun. 363:561-565.

Silanikove, N., F. Shapiro, U. Merin, and G. Leitner. 2013. Tissue-type plasminogen activator and plasminogen embedded in casein rule its degradation under physiological situations: Manipulation with casein hydrolysate. J. Dairy Res. 80:227-232.

Silanikove, N., F. Shapiro, and A. Shamay. 2003. Use of an ion-selective electrode to determine free $\mathrm{Ca}$ ion concentration in the milk of various mammals. J. Dairy Res. 70:241-243.

Silanikove, N., F. Shapiro, A. Shamay, and G. Leitner. 2005. Role of xanthine oxidase, lactoperoxidase, and NO in the innate immune system of mammary secretion during active involution in dairy cows: Manipulation with casein hydrolyzates. Free Radic. Biol Med. 38:1139-1151.

Silanikove, N., F. Shapiro, M. Silanikove, U. Merin, and G. Leitner. 2009. Hydrogen peroxide-dependent conversion of nitrite to nitrate as a crucial feature of bovine milk catalase. J. Agric. Food Chem. $57: 8018-8025$.

Simos, Y., A. Metsios, I. Verginadis, A.-G. D'Alessandro, P. Loiudice, E. Jirillo, P. Charalampidis, V. Kouimanis, A. Boulaka, G. Martemucci, and S. Karkabounas. 2011. Antioxidant and anti-platelet properties of milk from goat, donkey and cow: An in vitro, ex vivo and in vivo study. Int. Dairy J. 21:901-906.

Taponen, S., H. Simojoki, M. Haveri, H. D. Larsen, and S. Pyörälä. 2006. Clinical characteristics and persistence of bovine mastitis caused by different species of coagulase-negative staphylococci identified with API or AFLP. Vet. Microbiol. 115:199-207.

Titov, V. Y., O. V. Kosenko, V. I. Fisinin, and N. T. Klimov. 2010. Content of nitric oxide metabolites in cow milk in health and mastitis. Russ. Agric. Sci. 36:288-290.

Weiss, W. P. 2001. Effect of dietary vitamin C on concentrations of ascorbic acid in plasma and milk. J. Dairy Sci. 84:2302-2307. 